\title{
Biomass Production of Gynura procumbens Adventitious Roots in Different Type of Liquid Culture
}

\author{
${ }^{\square}$ Yosephine Sri Wulan Manuhara ${ }^{1}$, Dannis Yuda Kusuma ${ }^{1}$, \\ Rafika Lailiyatul Kurnia Sari ${ }^{1}$, Alfinda Novi Kristanti ${ }^{2}$
}

DOI: 10.15294/biosaintifika.v9i3.9670

${ }^{1}$ Department of Biology, Faculty Sains and Teknologi, Universitas Airlangga, Indonesia

${ }^{2}$ Department of Chemistry, Faculty Sains and Teknologi, Universitas Airlangga, Indonesia

\section{History Article}

Received 9 July 2017

Approved 4 November 2017

Published 31 December 2017

\section{Keywords}

Balloon-type bubble bioreactor; biomass production; Gynura procumbens; Liquid culture; Temporary immersion system

\begin{abstract}
Gynura procumbens has a potency to produce raw material for pharmaceutical industry. Liquid culture systems have significant effects on multiplication rates of organ, so the propagation technology to increase biomass of this plant or organ using the liquid culture system was necessary. This research was conducted to compare biomass production of adventitious roots of $G$. procumbens in different liquid culture (shake flask, temporary immersion bioreactor and balloon-type bubble bioreactor). Adventitious roots culture was maintained in Murashige and Skoog liquid medium supplemented with IBA (indole butyric acid) $5 \mathrm{mg} / \mathrm{L}$ and different concentrations of sucrose $(10,30,50 \mathrm{~g} / \mathrm{L})$. Result showed that the highest biomass production (fresh weight) was in shake flask that was 3.9-fold higher than initial explant, while in temporary immersion system was 5.12-fold higher than initial explant, and in balloon- type bubble bioreactor was 13.1-fold higher than initial explant. The highest enhancement of adventitious roots was occurred at sucrose supplementation of $50 \mathrm{~g} / \mathrm{L}$. Based on this research we found that the best type of liquid culture to increase biomass of $G$. procumbens adventitious roots was balloon-type bubble bioreactor. Scaling-up of adventitious root culture are necessary to fulfill the need of raw material for pharmaceutical industry and ballon-type bubble bioreactor was the most suitable method to scale up the performance.
\end{abstract}

\section{How to Cite}

Manuhara, Y. S. W., Kusuma, D. Y., Sari, R. L. K, \& Kristanti, A. N. (2017). Biomass Production of Gynura procumbens Adventitious Roots in Different Type of Liquid Culture. Biosaintifika: Journal of Biology \& Biology Education, 9(3), 523-529.

(C) 2017 Universitas Negeri Semarang $\square$ Correspondence Author:

Kampus C UNAIR, Mulyorejo Suyabaya, Jawa Timur 60115

E-mail: wulanmanuhara@gmail.com
p-ISSN 2085-191X e-ISSN 2338-7610 


\section{INTRODUCTION}

Gynura procumbens is one species of Asteracea known as a medicinal plant in Indonesia. It is a herb which have fast growth and widely distributed in South East Asia, including Indonesia, Malaysia, and Thailand. People use this plant as a traditional medicine for inflammation diseases, diabetes, cancer, and hypertension. This plant is potential to produce secondary metabolites containing alkaloid, flavonoid, and coumarin. Kaempferol, quercetin, rutin, and myricetin which belong to flavonoid have been isolated from $G$. procumbens leaves (Saiman et al., 2012). Flavonoid is potential as an antioxidant, especially myricetin and kaempferol (Kaewseejan et al., 2015). Ethyl acetate fraction of $G$. procumbens leaves have a potency as co-chemotherapy agent (Nurulita et al., 2012) and flavonoids contained in this plant can affect the vasodilatation process (Hoe et al., 2011; $\mathrm{Ng}$ et al., 2013). Generally, secondary metabolite in plant was found in leaves, roots, and stems. Propagation technology of those organs have a potency to produce raw materials of the secondary metabolites for pharmaceutical industry.

In vitro propagation of organ culture has developed in agar-based system and liquid-based system. Liquid culture systems have significant effects on multiplication rates and morphology of shoots, somatic embryos, microtubers or bulblets produced in vitro (Hvoslef-Eide \& Preil, 2005). Many researches have been developed to produced adventitious roots in liquid culture, such as production of biomass and bioactive compounds from adventitious roots of Eurycoma longifolia in ballon-type buble bioreactor system (Lulu et al., 2015), establishment of adventitious root culture of Stevia reboudiana Bertoni in a roller bottle system (Reis et al., 2011), production of biomass and bioactive compounds of Panax ginseng adventitious root in ballon-type bubble bioreactor (Wang et al., 2013), and production of biomass and metabolites accumulation in adventitious root culture of Glycyrhiza uralensis Fisch (Yin et al., 2014). In many cases, cultivation of roots in liquid culture have faster growth rate than in agar medium, such as growth rate of Justicia gendarussa hairy root (Wahyuni et al., 2017).

Compared to agar-based system, liquid system are more adaptable to automation so it is more suitable to reduce the number of labor and production costs, beside that the media can be changed easily during scaling-up, and cleaning of culture vessels is simplified. Using different concentration of sucrose in liquid medium was also performed to determine the optimum sucro- se concentration in enhancing the growth of adventitious roots.

Plant cell cultures are usually grown heterotrophically using simple form of sugar such as glucose, fructose, maltose, sucrose and their combination as an energy and carbon source. Among the various tested sugar, sucrose was found to be an ideal carbohydrate source for the biomass accumulation. For example, the various level of sucrose $(1-8 \%)$ tested in Gymnema sylvestre cell culture, $3 \%$ sucrose in the medium showed the maximum accumulation of biomass (Murthy et al., 2014); the same result was found in Ginkgo biloba cell cultures (Park et al., 2004); but in Bacopa monnieri shoot cultures, $2 \%$ sucrose was found optimal for biomass accumulation (Naik et al., 2010). This research was conducted to know the effect of sucrose concentration on biomass production of adventitious roots of G. procumbens in three liquid culture medium: shake flask culture, temporary immersion system, and ballon-type bubble bioreactor. Results of this research can be used as the basic method to scale up the production of biomass from $G$. procumbens adventitious roots.

\section{METHODS}

Gynura procumbens (Lours.) Merr was obtained from the Botanical Garden Purwodadi, Pasuruan, East Java, Indonesia. Adventitious roots were obtained from leaves, which were grown in MS (Murashige and Skoog) medium supplemented with IBA (indol butyric acid) 5 $\mathrm{mg} / \mathrm{L}$, sucrose $30 \mathrm{~g} / \mathrm{L}$ and agar $8 \mathrm{~g} / \mathrm{L}$.

Leaves were washed with detergent and then rinse thoroughly with tap water. Explant were sterilized with clorox $10 \%(\mathrm{v} / \mathrm{v})$ for $10 \mathrm{~min}$ and rinsed three times with sterile distilled water. Leaves were placed in sterile filter paper in petri dishes, cut $1 \mathrm{~cm}^{2}$ and then planted in MS medium supplemented with IBA $5 \mathrm{mg} / \mathrm{L}$, sucrose $30 \mathrm{~g} / \mathrm{L}$ and agar $8 \mathrm{~g} / \mathrm{L}$. Cultured were maintained in incubator room with temperature $25 \pm 3^{\circ} \mathrm{C}$ in dark condition. After 15 days of culture, adventitious roots were separated from leaves and used as explants for liquid culture method.

Adventitious root explants obtained from leaves explants, were pondered $2 \pm 0.5 \mathrm{~g}$ and then planted in $250 \mathrm{~mL}$ liquid MS supplemented with IBA $5 \mathrm{mg} / \mathrm{L}$ and various sucrose concentration $(10,30,50 \mathrm{~g} / \mathrm{L})$. Culture were maintained in shaker incubator and agitated at $100 \mathrm{rpm}$, temperature $25 \pm 3^{\circ} \mathrm{C}$ for 28 days. Treatments were replicated 3 times. At the end of culture process, adventitious roots were harvested and their fresh 
and dry weight were measured.

Liquid MS medium $(200 \mathrm{~mL})$ containing

IBA $5 \mathrm{mg} / \mathrm{L}$ were used to cultivate the adventitious roots $(2 \pm 0.1 \mathrm{~g})$ in temporary immersion bioreactor. There were three bioreactors which had immersion frequency of $15 \mathrm{~min}$ each $12 \mathrm{~h}$ and various concentration of sucrose $(10 ; 30 ; 50 \mathrm{~g} / \mathrm{L})$. Treatments were replicated 3 times. Culture were incubated at $25 \pm 3^{\circ} \mathrm{C}$ using 3 hours in light (General electric cool white fluorescent tubes) and 21 hours in dark for 28 days. Temporary immersion bioreactor were designed by modification of $\mathrm{BIT}^{\mathrm{B}}$ (Escalona et al., 1999). At the end of culture process adventitious roots were harvested and their fresh and dry weight were measured.

Volumes of BTBB vessel were $1 \mathrm{~L}$ with working volumes between 200-500 mL. Liquid MS medium $(400 \mathrm{~mL})$ supplemented with IBA $5 \mathrm{mg} / \mathrm{L}$ and various sucrose $(10,30,50 \mathrm{~g} / \mathrm{L})$ were used to cultivate the adventitious roots. The adventitious roots were weighed $2 \pm 0.1 \mathrm{~g}$ then planted in BTBB; and aeration volume was established at $0.25 \mathrm{vvm}$ (volume of gas per volume of liquid per minute). Cultures were incubated at $25 \pm 3^{\circ} \mathrm{C}$ for 28 days. Treatment were replicated three times. Ballon-type bubble bioreactor were designed by modification of Paek et al., 2005.

\section{RESULTS AND DISCUSSION}

Based on fresh weight and dry weight, at the end of culture (28 days), it was known that in low concentration of sucrose $(10 \mathrm{~g} / \mathrm{L})$, biomass of adventitious roots did not significantly different between the three type of liquid culture, but in higher sucrose concentration $(30,50 \mathrm{~g} / \mathrm{L})$ there was a significant different. Supplementation of sucrose $50 \mathrm{~g} / \mathrm{L}$ significantly increase the growth of adventitious roots. It could be seen that there was an enhancement of fresh weight compared to initial inoculum $(2 \mathrm{~g})$. In shake flask culture, it was obtained the final fresh weight of $7.8 \mathrm{~g}$ (3.9 fold higher than initial explant), in TIS was 10.24 g (5.12 fold higher than initial explant), and in BTBB was $26.20 \mathrm{~g}$ (13.1 fold higher than initial explant) (Table 1).

The plants propagated in liquid culture are usually submerged in medium. Since most plants propagated are terrestrial plants (not aquatic), and under their natural habitat, submerged condition is usually harmful to the plants. The shake culture method is considered to be an intermediate in establishing bioreactor technique. The growth characteristic in liquid medium are quite different, so the optimization of cultured condition is needed. There are many problems in liquid culture, such as asphyxia (less oxygen) and hyperhydricity which was caused by low oxygen and submerged condition in medium. In order to overcome these problems, temporary immersion system and ballon-type bubble bioreactor can be adopted.

Temporary immersion system (TIS) is a system which was used to eliminate hyperhydricity and asphyxia by adjusting the immersion times (Etienne \& Berthouly, 2002). This research was obtained the biomass of $G$. procumbens adventitious roots in TIS higher than in shake flask culture. Fresh weight of adventitious roots in shake flask culture had average biomass of 3.2 fold higher than initial inoculum at different concentration of sucrose, whereas in TIS, the average of adventitious roots biomass was 4 fold higher than initial inoculum (Table 1). Immersion frequency of 15 min each $12 \mathrm{~h}$ provided opportunities for adventitious roots to absorb nutrient and oxygen as well as reducing the occurrence of hyperhydricity and asphyxia. Meanwhile, when the explant did not immerse in liquid medium, respiration of the cell still could take place because the oxygen

Table 1. Fresh weight and dry weight of Gynura procumbens adventitious roots in three different liquid culture and different sucrose concentrations

\begin{tabular}{lcccc}
\hline $\begin{array}{l}\text { Type of liq- } \\
\text { uid culture }\end{array}$ & $\begin{array}{c}\text { Sucrose concen- } \\
\text { tration }(\mathrm{g} / \mathrm{L})\end{array}$ & $\begin{array}{c}\text { Initial inoculum } \\
(\mathrm{g})\end{array}$ & $\begin{array}{c}\text { Fresh weight } \\
(\mathrm{g})\end{array}$ & $\begin{array}{c}\text { Dry weight } \\
(\mathrm{g})\end{array}$ \\
\hline Shake flask & 10 & 2.02 & $5.00 \pm 1.2$ & $0.13 \pm 0.03$ \\
TIS & & 2.04 & $5.30 \pm 0.6$ & $0.11 \pm 0.02$ \\
BTBB & & 2.04 & $5.20 \pm 2.8$ & $0.15 \pm 0.03$ \\
Shake flask & 30 & 2.01 & $6.50 \pm 1.3$ & $0.14 \pm 0.08$ \\
TIS & & 2.00 & $8.70 \pm 0.7$ & $0.15 \pm 0.06$ \\
BTBB & & 2.06 & $14.95 \pm 0.8$ & $0.49 \pm 0.33$ \\
Shake flask & 50 & 2.00 & $7.80 \pm 1.9$ & $0.28 \pm 0.01$ \\
TIS & & 2.02 & $10.24 \pm 0.6$ & $0.19 \pm 0.06$ \\
BTBB & & 2.10 & $26.20 \pm 1.9$ & $1.52 \pm 1.11$ \\
\hline
\end{tabular}


in the room culture were available. In shake flask culture, oxygen dissolved in liquid medium was limited resulted in slower growth of explants and more occurrence of hyperhidrycity.

Different type of liquid culture influenced adventitious roots growth rate. Beside that, increasing of sucrose concentration also increased the adventitious roots biomass. Different type of liquid culture gave influence in growth of adventitious roots if in culture media had enough sucrose to support carbon source which was needed by plant cell for metabolism. Between these three different types of liquid culture, the best technique to increase the adventitious roots of $G$. procumbens was ballon-type bubble bioreactor ( $\mathrm{Fi}$ gure $1 \mathrm{c}-\mathrm{e})$, because this technique could increase the growth of adventitious roots highest than the others. Morphology of root produced in three culture method had no significant different (Figure 1f-h).
Culture in balloon-type bubble bioreactor use liquid medium with forced aeration which stimulates the growth rate. The bubble creates less shear forces, therefore BTBB was suitable for plant organ cultures (Paek et al., 2005). In balloontype bubble bioreactor system, the average of increasing biomass was 13.1 fold higher than initial inoculum and was almost 2 fold higher than temporary immersion system. Root biomass was also found to be higher in the bioreactor cultures than in the shake flask culture of Astragalus membranaceus (Wu et al., 2011) and Eurycoma longifolia (Lulu et al., 2015). In medium supplemented with sucrose $50 \mathrm{~g} / \mathrm{L}$ adventitious roots growth rate was highest. In BTBB system adventitious root growth rate was highest, especially in medium supplemented with sucrose $50 \mathrm{~g} / \mathrm{L}$.

Many factors could influence the bioreactor system. Proper oxygen supply and gaseous exchange are two critical factors. The existence
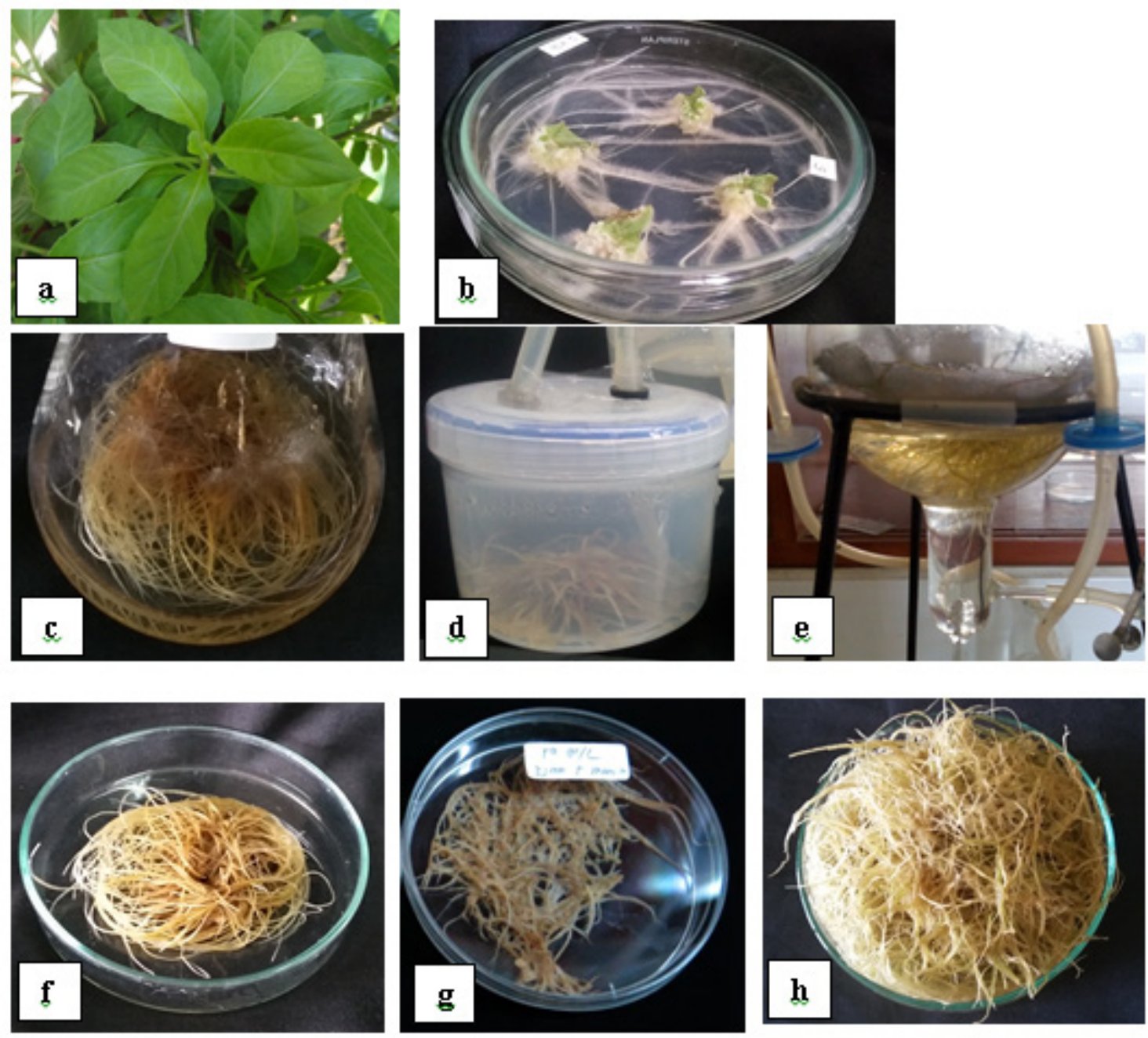

Figure 1. Adventitious roots of G. procumbens after 28 days culture in different type of liquid culture and $50 \mathrm{~g} / \mathrm{L}$ sucrose concentration, (a) mother plant, (b) adventitious root induction in MS solid medium, (c) shake flask culture, (d) temporary immersion bioreactor, (e) ballon-type bubble bioreactor, (f-h) morphology of adventitious root. 
of gaseous flow more than required by the culture can caused evaporation of some essential components, especially water. Improper aeration gives rise to foaming problem. Temperature should be in appropriate range so it will not affect the bioprocess activities in the culture with the maintenance of the metabolite production. The optimum temperature should be at $20-30^{\circ} \mathrm{C}$ but can be vary from species to species as well as with the type of products. Consideration of shear stress is also necessary for the hairy roots as it can causing reduction in productivity. Immersion time is a critical factor for root cultures and over lodging can cause hyperhydricity. Inoculum size can also affect the productivity, in which too many tissue mass formulated can cause problems during scaling up (Sharma et al., 2014).

In some research, temporary immersion system have been used for many purposes, for example to increase the somatic embryogenesis of peach palm (Steinmacher et al., 2011), enhance the propagation of Chinese water chestnut (Gao et al., 2015), and micropropagation of embryogenic callus of oil palm (Elaeis guineensis Jacq.) (Marbun et al., 2015; Gomes et al., 2016). In some cases, temporary immersion system could reduce the hyperhydricity, because hyperhydricity is a major problem during in vitro culture of many crops in liquid culture system. Hyperhydricity is a disorder of tissue-cultured plants where leaves become translucent and stem become swollen, distorted and brittle. Although numerous hypotheses have been put forward to explain hyperhydricity but there is still a lack of knowledge about the nature of signals which was responsible for hyperhydricity (Dewir et al., 2014). This study showed that the percentage of dry weight adventitious roots in the balloon-type bubble bioreactor was higher than flask culture and temporary immersion system.

In all type of liquid cultures, supplementation of sucrose that was higher than $10 \mathrm{~g} / \mathrm{L}$ could increase the biomass (FW and DW) of adventitious roots. Sucrose is hydrolyzed into two monosaccharides, glucose and fructose by invertase which bounds extracellularly and/or cell wall during the initial culture period (Cui et al., 2010). In this study, the higher sucrose supplementation can increase the biomass production. The highest enhancement was occurred at $50 \mathrm{~g} / \mathrm{L}$ of sucrose supplementation. This result also occurred in adventitious root culture of Echinacea angustifolia (Baque et al., 2012) High concentration of sucrose had significant effect on the production of ginseng saponin of Panax notoginseng. A high sugar level is able to the synthesis the ginseng saponin, it may be due to the high osmotic pressure which was caused by high sugar concentration. The cell growth was reduced at sucrose concentration of $60 \mathrm{~g} / \mathrm{L}$, the maximum production of crude ginseng saponin was achieved at sucrose concentration of $40 \mathrm{~g} / \mathrm{L}$. A dual role of sucrose as a carbon source and an osmotic agent was observed in Solanum melongena (Mukherjee et al., 1991). Recently, sugars have been recognized as a signaling molecules that affect the growth, development and metabolism of cultured cells (Wang \& Weathers, 2007). Therefore, the selection of suitable carbohydrate source at an appropriate concentration is key criterion for biomass and secondary metabolite production in cell and organ cultures.

Based on this research we found that high concentration of sucrose could increase the biomass of $G$. procumbens adventitious roots in different type of liquid culture, so at the next study to scale up of adventitious roots production, sucrose concentration was necessary things to be noted.

\section{CONCLUSION}

Adventitious roots of G. procumbens was successfully developed in three types of liquid cultures, but the highest biomass was obtained in balloon-type bubble bioreactor system. Scalingup of adventitious root culture are necessary to develop in the next study because this plant was potential as a source of raw materials for pharmaceutical industry.

\section{ACKNOWLEDGMENT}

Research was funded by grant from Directorate of Research and Community Services, Ministry of Research, Technology, and Higher Education, Indonesia (Grant Number 951/ UN3.14/2016).

\section{REFERENCES}

Baque, M. A., Elgirban, A., Lee, E. J., \& Paek, K. Y. (2012). Sucrose regulated enhanced induction of anthraquinone, phenolics, flavonoids biosynthesis and activities of antioxidant enzymes in adventitious root suspension cultures of Morinda citrifolia (L.). Acta Physiology Plant, $34(2), 405-415$.

Cui, X. H., Chakrabarty, D., Lee, E. J., \& Paek, K. Y. (2010). Production of adventitious roots and secondary metabolites by Hypericum perforatum L. in a bioreactor. Bioresource Technology, 101(12), 4708-4716.

Dewir, Y. H., Indoliya, Y., Chakrabarty, D., \& Paek, K. Y. (2014). Biochemical and physiological 
aspects of hyperhydricity in liquid culture system. In Production of Biomass and Bioactive Compounds Using Bioreactor Technology (pp. 693-709). Springer Netherlands.

Escalona, M., Lorenzo, J. C., González, B., Daquinta, M., González, J. L., Desjardins, Y., \& Borroto, C. G. (1999). Pineapple (Ananas comosus L. Merr) micropropagation in temporary immersion systems. Plant Cell Reports, 18(9), 743-748.

Etienne, H. \& Berthouly, M. (2002). Temporary immersion system in plant micropropagation. Plant, Tissue, and Organ Culture, 69(3), 215-231.

Gao, M., Jiang, W., Wei, S., Lin, Z., Cai, B., Yang, L., Lou, C., He, X., Tan, J., \& Chen, L. (2015). High-efficiency propagation of chinese water chestnut [Eleocharis dulcis (Burm.f.) Trin ex Hensch] using a temporary immersion bioreactor system. Plant Cell, Tissue and Organ Culture, 121(3), 761-772.

Gomes, H. T., Bartos, P. M. C., Balzon, T. A., \& Scherwinski-Pereira, J. E. (2016). Regeneration of somatic embryo of oil palm (Elaeis guineensis) using temporary immersion bioreactors. Industrial Crops and Products, 89, 244-249.

Hoe, S. Z., Lee, C. N., Mok, S. L., Kamaruddin, M. Y., \& Lam, S. K. (2011). Gynura procumbens Merr. Decrease blood pressure in rats by vasodilatation via inhibition of calcium channels. CLINICS, 66(1), 143-150.

Hvoslef-Eide, K. A. \& Preil, W. (2005). Liquid Culture System for In Vitro Plant Propagation. Springer, Netherlands.

Kaewseejan, N., Sutthikhum, V., \& Siriamornpun, S. (2015). Potential of Gynura procumbens leaves as source of flavonoid-enriched fraction with enhanced antioxidant capacity. Journal of Functional Food, 12(1), 120-128.

Lulu, T., Park, S. Y., Ibrahimuu, R., \& Paeky, K. Y. (2015). Production of biomass and bioactive compounds from adventitious roots by optimization of culturing conditions of Eurycoma longifolia in balloon-type bubble bioreactor system. Journal of Bioscience and Bioengineering, 119(6), 712-717.

Marbun, C. L. M., Toruan-Mathius, N., Utomo, C., \& Liwang, T. (2015). Micropropagation of embryogenic callus of oil palm (Elaeis guineensis Jacq.) using temporary immersion system. Procedia Chemistry, 14, 122-129.

Mukherjee, S. K., Rathinasabapathi, B., \& Gupta, N. (1991). Low sugar and osmotic requirements for shoots regeneration for leaf pieces of Solanum melongena L., Plant Cell, Tissue and Organ Culture, 25(1), 13-16.

Murthy, H. N., Dandin, V. S., Zhong, J. J., \& Paek, K. Y. (2014). Strategies for enhanced production of plant secondary metabolites from cell and organ cultures. In Production of biomass and bioactive compounds using bioreactor technology (pp. 471-508). Springer Netherlands.

Naik, P. M., Manohar, S. H., Praveen, N., \& Murthy, H. N. (2010). Effect of sucrose and $\mathrm{pH}$ levels on in vitro regeneration from leaf explants of Bocopa monnieri and accumulation of bacoside A in regenerated shoots. Plant Cell, Tissue and Organ Culture, 100(2), 235-239.

Ng, H. K., Poh, T. F., Lam, S. K., \& Hoe, S. Z. (2013). Potassium channel openers and prostacyclin play a crucial role in mediating the vasorelaxant activity of Gynura procumbens. BMC Complementary and Alternative Medicine, 13(1),188.

Nurulita, N. A., Meiyanto, E., Sugiyanto, Matsuda, E., \& Kawaichi, M. (2012). Gynura procumbens modulates the microtubules integraty and enhances distinct mechanism on doxorubicin and 5-flurouracil-induced breast cancer cell death. Oriental Pharmacy Experimental Medicine, 12(3), 205-218.

Paek, K. Y., Chakrabarty, D., \& Hahn, E. J. (2005). Application of bioreactor system for large scale production of horticultural and medical plants. Plant, Cell, Tissue and Organ Culture, 81(3), 287300.

Park, Y. G., Kim, S. J., Kang, Y. M., Jung, H. Y., Prasad, D. T., Kim, S. W., Chung, Y. G., \& Choi, M. S. (2004). Production of ginkgolides and bilobalide from optimized the Ginkgo biloba cell cultures. Biotechnology and Bioprocess Engineering, 9(1), 41-46.

Reis, R. V., Luis Borges, A. P. P., Chierrito, T. P. C., de Souto, E. R., de Souza, L. M., Iacomini, M., de Oliveira, A. J. B., \& Goncalves, R. A. C. (2011). Establisment of adventitious root culture of Stevia rebaudiana Bertoni in roller bottle system. Plant Cell, Tissue and Organ Culture, 106(2), 329335.

Saiman, M. Z., Mustafa, N. R., Schulte, A. E., Verpoorte, R., \& Choi, Y. H. (2012). Induction, characterization, and NMR-based metabolic profiling of advetitious root cultures from leaf explants of Gynura procumbens. Plant Cell, Tissue and Organ Culture, 109(3), 465-475.

Sharma, P., Sharma, S., Yadav, S., Srivastava, A., Purohit, I., \& Shrivastava, N. (2014). Plant derived bioactive molecules: culture vessels to bioreactors. In Production of Biomass and Bioactive Compounds Using Bioreactor Technology (pp. 47-60). Springer Netherlands.

Steinmacher, D. A., Guerra, M. P., Saare-Surminski, K., \& Lieberei, R. (2011). A temporary immersion system improve in vitro regeneration of peach palm through secondary somatic embryogenesis. Annals of Botany, 108(8), 14631475.

Wahyuni, D. K., Hafida, S. N., Ermayanti, T. M., Wardoyo, B. P. E., Purnobasuki, H., \& Utami, E. S. W. (2017). Hairy roots induction on Justicia gendarussa by various density of Agrobacterium rhizogenes strain LB 510, Biosaintifika: Journal of Biology \& Biology Education, 9(1), 2632.

Wang, Y., \& Weathers, P. J. (2007). Sugars proportionately affect artemisinin production. Plant cell reports, 26(7), 1073-1081. 
Yosephine Sri Wulan Manuhara et al. / Biosaintifika 9 (3) (2017) 523-529

Wang, J., Zhang, J., Gao, W., Wang, Q., Yin, S., Liu, H., \& Man, S. (2013). Identification of triterpenoid and flavonoids, step-wise aeration treatment as well as antioxidant capacity of Glycyrrhiza uralensis Fisch. Cell. Industrial Crops and Products, 49, 675-681.

Wu, S. Q., Lian, M. L., Gao, R., Park, S. Y., \& Piao, X. C. (2011). Bioreactor application on adventitious root culture of Astragalus membranaceus.
In Vitro Cellular \& Developmental Biology-Plant, 47(6), 719-724.

Yin, S., Zhang, Y., \& Gao, W. (2014). Effects of nitrogen source and phosphate concentration on biomass and metabolites accumulation in adventitious root culture of Glycyrrhiza uralensis Fisch. Acta Physiologiae Plantarum, 36(4), 915921. 